\title{
VISCERAL LEISHMANIASIS IN THE ADEN PROTECTORATE
}

\author{
Major IAN MICHIE, M.B., M.R.C.P.(Edin.), R.A.M.C. \\ The Queen Alexandra Military Hospital, Millbank, London.
}

SYSTEMIC leishmaniasis is a condition rarely seen in British hospitals. In the last few months four patients with this condition were admitted to a military hospital in the United Kingdom. All were soldiers who presented either during service in, or within one year of returning to the U.K. from, the Aden Protectorate. Although both the cutaneous and systemic forms of leishmaniasis are present in the highlands of the Yemen; San'a and Taiz being suspected foci (1), no cases had previously been reported from troops operating in the Aden Protectorate.

All four patients had served in the Radfan area but the only common position was Thumiar, a tented camp initially on sand and latterly on concrete. Two patients $(1$ and 2 case reports) had also been to Wadi Taym, a large formerly fertile valley with some grass, bushes and trees in sheltered areas of the Wadi and along the water courses, and to Mukeiras a high altitude post with tented accommodation and a cool and pleasant climate on the Yemen border. The first three patients in addition had been to the transit camp which was tented, sited on the edge of the desert about 5 miles outside the town of Aden. The weather was hot and humid, with a sand and dust laden wind blowing for most of the day.

The first patient with kala-azar in whom intracellular bodies were seen was a German soldier (2) who developed the disease in Peking in 1900 and later died in Germany. It was not, however, until 1903, after Leishman had published his discovery that these bodies were in fact parasitic, that their significance was appreciated. Lieut.-Colonel Donovan of the Indian Medical Service, working independently, published his finding in the same year and so the parasites, which occur in two forms, became known as the Leishman-Donovan (L.D.) bodies. The vector is the sandfly (Phlebotomus spp.). Many workers regard the condition as being primarily a zoonosis.

De Alencar (3) in Brazil described a focus of canine kala-azar when he found 11 dogs out of a total of 80 examined to be suffering from the disease. Heich (4) isolated three strains of Leishmania from gerbils and one from ground squirrels. The rodent strains were inoculated into volunteers, and produced a local lesion in some, but no cases of visceral leishmaniasis occurred.

In the Sudan outbreak of 1961 to 1963 the disease apparently did not arise from any one focus and its spread suggested that the disease existed previously as a widespread zoonosis, affecting man as a result of a combination of unknown factors. During the outbreak, however, there was evidence that there was man-sandfly-man and even direct man to man transmission of the disease(5). In France animals found with the disease have been the dormouse, the common squirrel, the field mole and the fox(6). A number of other animals have been incriminated including jackals in Eastern Russia while the striped hamster in China has been shown to be very susceptible to the disease, although on only one occasion has it been found to be infected in the wild state.

The incubation period for the disease is indefinite, usually three to six months but ranging from one week up to 9 years(7). Six hundred and forty cases of kala-azar have 
been reported in France since 1918(6) with the main foci around Marseilles and Nice. With the current vogue of summer holidays on the French Riviera, it is likely that a few sporadic cases will turn up in British hospitals. If the disease is not kept constantly in mind the condition will be both missed and misdiagnosed.

\section{Case Reports}

Case No.1. A 30 year old soldier was admitted to the Military Hospital, Tidworth on 27th February 1965 complaining of anorexia, weight loss, night sweats, and rigors, since December 1964, when he was serving in Aden. He did not report sick and on returning to U.K. he went on leave for five weeks. During this period the frequency of his rigors increased from 2-3 times a week to nightly. In all he had lost two stones in weight and had noticed that the skin of his calves was patchily pigmented. There was no nausea or vomiting. He had served in the Aden Protectorate from 23rd May 1964 until 7th February 1965. He had spent seventeen weeks of this time in the Aden transit camp, ten weeks in Wadi Taym, five weeks at Thumiar and four weeks at Mukeiras. In 1956 he had malaria while serving in Malaya but there was no other relevant past or family history.

He was transferred to the Queen Alexandra Military Hospital on 29th April 1965 where he showed clinical anaemia, a dusky pigmentation of the hands and face with darker blotchy pigmentation of the legs. Both the liver and spleen were enlarged. The spleen almost reached the umbilicus and was firm in consistency. The temperature was $102^{\circ} \mathrm{F}$ with a pulse rate of 90 per minute and a blood pressure $105 / 65$. There was marked wasting of both calves but no reflex or sensory abnormality. The haemoglobin was $6.0 \mathrm{G}$ per $100 \mathrm{ml}$; the packed cell volume was 20 per cent and the mean cell haemoglobin content 30 per cent. The white cell count was 1,150 per $\mathrm{cmm}$, with a normal differential, less than 1 per cent of reticulocytes and the ESR was $110 \mathrm{~mm}$ (Westergren) in the first hour. The platelet count was 66,000 per cmm. The direct Coomb's test was negative. Repeated blood films failed to show malarial parasites or Leishman-Donovan bodies. The prothrombin time was 14 seconds against a control of 13 , the serum bilirubin less than $1.0 \mathrm{mgm}$ and alkaline phosphatase $5.4 \mathrm{King}$-Armstrong (K.A.) units. Total serúm proteins were $7.5 \mathrm{G}$ per $100 \mathrm{ml}$. with $2.42 \mathrm{G}$ of albumin and $5.8 \mathrm{G}$ of globulin. The betaglobulin was. $0.91 \mathrm{G}$ and the gamma globulin $2.73 \mathrm{G}$. The serum folate levels on two successive days were $2: 1 \mathrm{~m} \mu \mathrm{g}$. per $\mathrm{ml}$. and the serum 'B $12460 \mu \mu \mathrm{g}$. per ml. and $500 \mu \mu \mathrm{g}$. per $\mathrm{ml}$. The Formimino-glutamic acid (FIGLU) test was positive. Blood cultures were sterile. The formol-gel test was negative. The urine showed a proteinuria of $60 \mathrm{mgm}$. per cent with granular casts and 18-20 red blood cells per high power field. X-ray of chest was normal.

A bone marrow biopsy showed a moderate megaloblastosis with mainly intermediate and some late megaloblasts. Megakaryocytes were plentiful. No LeishmanDonovan bodies were seen. Splenic aspiration with a hypodermic needle showed no L.D. bodies, but splénic biopsy with the $1 \mathrm{~mm}$. Menghini needle produced a good specimen of splenic tissue and on smear extracellular L.D. bodies were demonstrated in moderate numbers scattered through the stroma.

Progress. He was transfused with 4 pints of packed cells and on 5th May 1965 was started on a 10 day course of sodium stibogluconate (Pentostam) $0.6 \mathrm{G}$ daily intravenously. Within 48 hours he became afebrile and remained so for 72 hours when there was a recrudescence of fever up to $101.8^{\circ}$ for 48 hours followed by a purpuric eruption on both ankles and feet: At this time the platelet count was 116,000 per $\mathrm{cmm}$., the bleeding 
time 45 secs. Hess's test was negative. The haemoglobin at this stage had fallen again to $6.4 \mathrm{G}$ per $100 \mathrm{ml}$., the white cell count to 2,300 per $\mathrm{cmm}$, and a further 4 pints of fresh blood were transfused with resultant rise of haemoglobin to $10.5 \mathrm{G}$ per $100 \mathrm{ml}$. Following transfusion a further rise of temperature occurred up to $103.5^{\circ} \mathrm{F}$ associated with a marked increase in extent and degree of severity of purpura. He was treated with prednisolone $40 \mathrm{mgm}$. daily and within 48 hours his fever had returned to normal, and the dosage was gradually reduced. Two further 10 day courses of Pentostam were given with two week intervals, without subjective or objective evidence of intolerance at this dosage. Electrocardiograms showed no abnormality. He was also given folic acid $5 \mathrm{mgms}$. three times a day orally.

When last seen in September 1965 he was a healthy looking asymptomatic individual who had lost his previous pigmentation. The spleen tip was just palpable on full inspiration and there was no hepatomegaly. The haemoglobin had risen to $15.2 \mathrm{G}$ per 100 $\mathrm{ml}$, the white cell count to 6,300 per $\mathrm{cmm}$, and the ESR was $19 \mathrm{~mm}$ in one hour. The total serum protein was $7.3 \mathrm{G}$ per $100 \mathrm{ml}$. with a plasma albumin of $4.25 \mathrm{G}$ and globulin of $3.05 \mathrm{G}$; the gamma globulin now being $1.7 \mathrm{G}$ and the betaglobulin $0.47 \mathrm{G}$.

Case No. 2. A 27 year old officer was admitted to the Military Hospital, Tidworth, on 28th June 1965 with a four day complaint of evening fever and headache, drenching night sweats, malaise and weakness in the mornings. A single rigor had occurred two nights before. He had previously served in North Africa from 1960-63; had been for four months in Tanganyika in 1963 and following this had served in the Aden Protectorate from May 1964 to February 1965. During this time he had been for fifteen weeks in the transit camp, nine weeks in Wadi Taym and five weeks in Thumiar. He returned to the U.K. in February 1965.

On examination at Tidworth the temperature was $99.4^{\circ} \mathrm{F}$, the pulse rate 100 per minute and neither the liver nor spleen were felt. The haemoglobin was $13.0 \mathrm{G}$ per 100 $\mathrm{ml}$, the white cells 3,800 per $\mathrm{cmm}$ with a normal differential. Platelets were reported as plentiful. Repeated blood films failed to show malarial parasites. The urine was normal. X-ray of the chest was also normal. Two days after admission to hospital both liver and spleen became palpable and the patient developed a swinging fever up to $104.5^{\circ} \mathrm{F}$. Nevertheless, he did not look ill. Blood culture failed to grow any organism and agglutination tests for brucellosis and typhus were negative. A bone marrow biopsy failed to show any Leishman-Donovan bodies.

He was transferred to the Queen Alexandra Military Hospital on 8th July. The spleen had by now become larger and there was increased pigmentation over the dorsum of the distal phalanges of the fingers and toes. Fever continued as illustrated in Fig. 1. The white cell count fell to 1,900 per $\mathrm{cmm}$, platelet to 94,000 per $\mathrm{cmm}$, but haemoglobin remained at $13.6 \mathrm{G}$ per $100^{\circ} \mathrm{ml}$. The ESR was $34 \mathrm{~mm}$. in the first hour and the serum folate was 3.4 and $3.7 \mathrm{~m} \mu \mathrm{g}$ per $\mathrm{ml}$. SGOT was 120 units and SGPT 92 units and the alkaline phosphatase was 5 KA units. The serum electrolytes were normal.

No Leishman-Donovan bodies were found in the blood. Marrow biopsy was re peated, $5 \mathrm{ml}$. of cellular material being aspirated but no Leishman-Donovan bodies were seen on initial examination. After several days searching, however, scanty L.D bodies were found. Culture of marrow on N.N.N. medium was negative after two weeks. Hamster inoculation was performed with the production of the systemic disease in the animal. In view of the initially negative marrow, splenic aspiration was performed with a 
hypodermic needle but again no Leishman-Donovan bodies were demonstrated. A percutaneous splenic biopsy with a Menghini needle, $1 \mathrm{~mm}$. in diameter, under local anaesthesia was performed and a small portion of spleen obtained. On examination of a smear of this tissue scanty L.D. bodies were demonstrated. No growth was obtained on N.N.N. medium but animal inoculation again resulted in clinical disease.

Treatment was started with sodium stibogluconate (Pentostam) $0.6 \mathrm{G}$ intravenously daily for 10 days. The temperature returned to normal in 4 days and there were no further episodes of pyrexia. (Fig. 1.). Two further 10 day courses of Pentostam, with two weeks

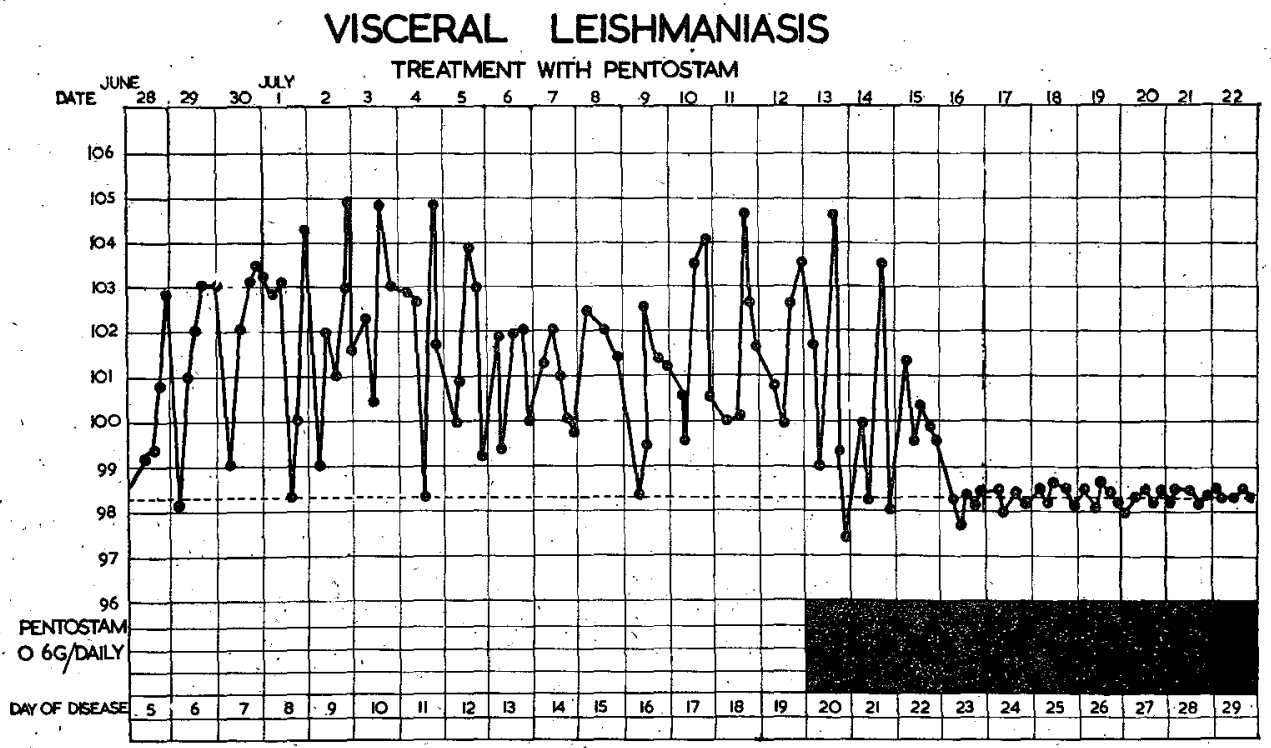

Fig. 1

interval between courses were given without side effects. When the patient was last seen in September 1965 he was asymptomatic, the liver edge was just felt below the costal margin and the spleen could just be felt with the patient in the right lateral position. The haemoglobin had risen to $15.5 \mathrm{G}$ per $100 \mathrm{ml}$, and the white blood cells to 5,500 per $\mathrm{cmm}$. The ESR had fallen to $2 \mathrm{~mm}$. in the first hour. The serum proteins had also reverted to normal, total protein $7.5 \mathrm{G}$ per $100 \mathrm{ml}$, albumin $4.5 \mathrm{G}$ per $100 \mathrm{ml}$, globulin 3.4 G per $100 \mathrm{ml}$, betaglobulin $0.99 \mathrm{G}$ per $100 \mathrm{ml}$ and gamma globulin 1.61 per $100 \mathrm{ml}$.

Case No. 3. A 30 year old West Indian soldier was admitted to the Military Hospital, Tidworth on 21st September 1965 complaining of abdominal discomfort, fever, headache, drenching night sweats and rigors every night for the previous week. His appetite was poor but there was no nausea or vomiting. Ten months previously he had reported to his medical officer on account of small patches of depigmentation that had developed in particular over the upper part of his trunk, but as he had no other symptoms and appeared to be well, he was reassured and no further action taken. There was no other relevant past or family history. He had served in the Aden Protectorate from May till October 1964, had stayed in the transit camp for 8 days and for the remainder of the time was stationed at Thumiar. On examination at Tidworth the temperature was $102^{\circ} \mathrm{F}$, the pulse rate 100 per minute and the spleen moderately enlarged and firm. The haemoglobin was $12.4 \mathrm{G}$ per $100 \mathrm{ml}$ and the white blood count 9,600 per $\mathrm{cmm}$, with a normal 


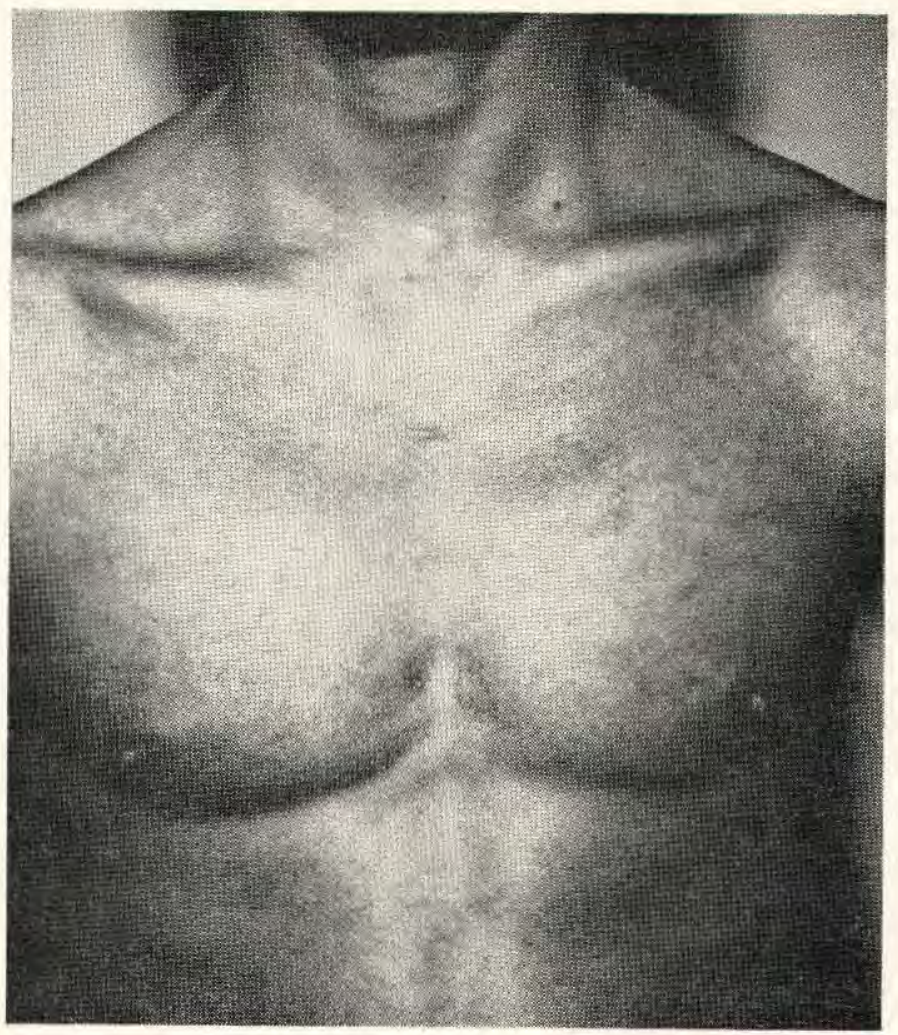

Fig. 2

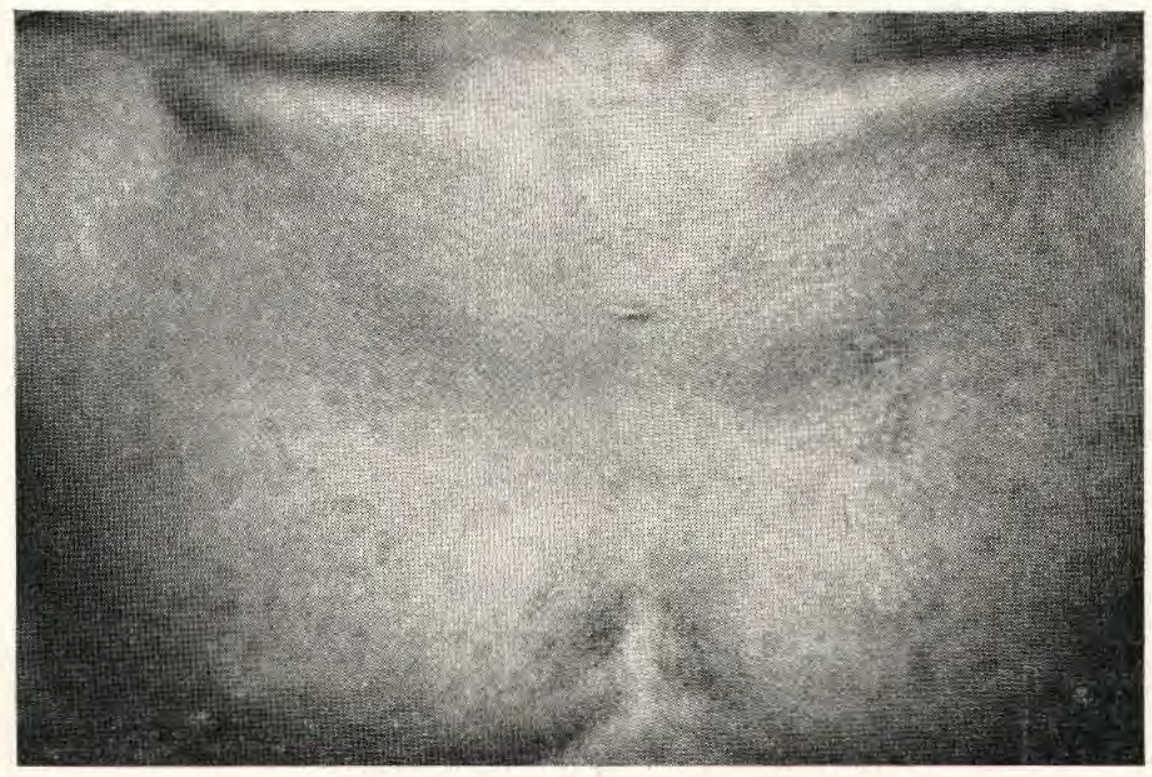

Fig. 3

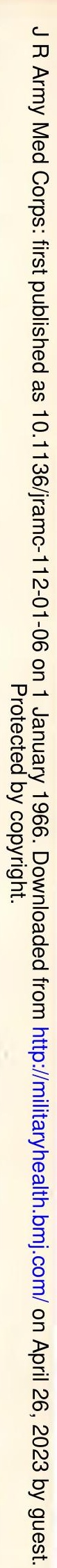


differential count. Repeated blood films failed to reveal malarial parasites, blood culture was sterile and X-ray of chest normal. The urine was normal. Despite the negative findings for malaria it was felt justifiable to give him a five day course of chloroquine. No clinical response was obtained, the fever persisting, often with two spikes in one day and the liver becoming enlarged.

The patient was transferred to the Queen Alexandra Military Hospital on 5th October 1965 where the clinical findings were confirmed. The patchy depigmentation was striking and is shown in Figs 2 and 3. The haemoglobin was $10.8 \mathrm{G}$ per $100 \mathrm{ml}$ and white cell count 1,300 per cmm, with 11 per cent eosinophils. The ESR was $50 \mathrm{~mm}$. in the first hour and the platelet count 168,000 per $\mathrm{cmm}$. The serum bilirubin was $1.0 \mathrm{mg}$ per cent, the alkaline phosphatase 49 KA units, the SGOT 180 units and the SGPT 143 units. Total serum proteins were $7.4 \mathrm{G}$ per $100 \mathrm{ml}$, albumin being $3.71 \mathrm{G}$ and globulin $3.89 \mathrm{G}$, the betaglobulin was $0.441 \mathrm{G}$ and the gamma globulin $2.93 \mathrm{G}$. The prothrombin time was 14 seconds against a control time of 13 seconds. The serum folate was $5.6 \mathrm{~m} \mu \mathrm{g}$ per $\mathrm{ml}$ and serum B $121420 \mu \mu \mathrm{g}$ per ml. The formol-gel test was positive. Blood films showed no Leishman-Donovan bodies. A bone narrow biopsy showed marked hypoplasia with scanty Leishman-Donovan bodies which were mainly extra-cellular.

Treatment with Pentostam $0.6 \mathrm{G}$ daily, intravenously was given and the patient's condition improved within 24 hours with a marked increase in appetite. The fever ceased in three days and the liver and spleen gradually decreased in size. Four days after starting Pentostam the haemoglobin was $12.8 \mathrm{G}$ per $100 \mathrm{ml}$, the white cell count having risen to 2,700 per $\mathrm{cmm}$. with a normal differential and a platelet count of 141,000 per $\mathrm{cmm}$.

Case No. 4. A 23 year old guardsman was admitted to the Queen Alexandra Military Hospital on 26th October 1965 with a history of night sweats, rigors and loss of weight of six weeks duration. He had served in Kenya from September 1960 till April 1961, in Bahrein from April 1961 till September 1961, and in the Aden Protectorate from October 1964 till October 1965. Of this service in Aden he had spent thirty-three weeks in the Salerno lines camp at Little Aden and eighteen weeks in the Radfan, thirteen of which had been in Thumiar.

In July 1965 he had been admitted to the Medical Reception Station at Falaise with an acute febrile illness, headache and vomiting with a few enlarged cervical glands. The clinical findings at this time are not available but a diagnosis of sandfly fever was made and he became asymptomatic in a few days. He remained well till early September 1965 when he developed evening fever with rigors, two or three times a week, night sweats, a central abdominal heavy sensation, anorexia and occasional vomiting. He reported sick after three weeks and after observation at the Casualty Clearing Post, Habylan and the Medical Reception Station Falaise, he was transferred to the Royal Air Force Hospital, Steamer Point.

On examination there he was reported as a "fit looking lad", with a temperature of $101^{\circ} \mathrm{F}$, a pulse rate of 84 per minute and blood pressure of $120 / 60$.

Minimal generalised lymphadenopathy especially in the cervical region and a moderate non tender enlargement of the liver and spleen were noted. The haemoglobin was $13.9 \mathrm{G}$ per $100 \mathrm{ml}$, the white cell count 1,900 per $\mathrm{cmm}$, with a normal differential count. The ESR was $39 \mathrm{~mm}$. in the first hour. Repeated blood films for malarial parasites were negative, serum electrolytes were normal and the blood urea was 43 mgms. per 


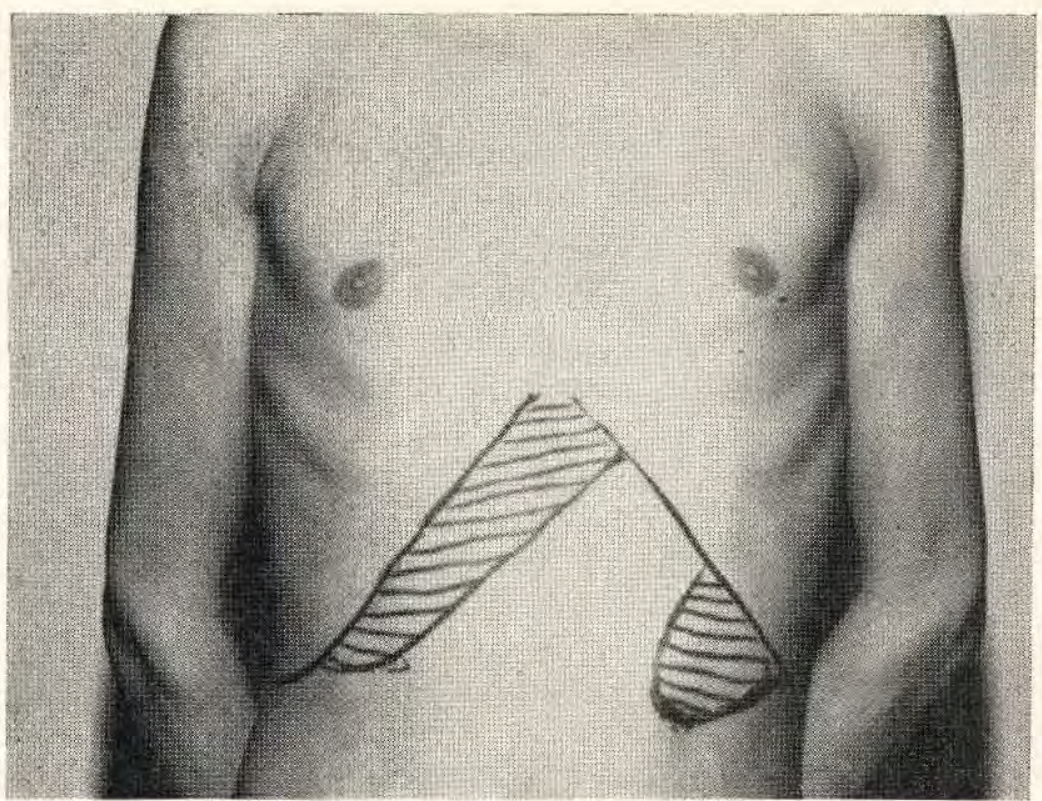

Fig. 4

cent. The serum bilirubin was $0.8 \mathrm{mgms}$. per $100 \mathrm{ml}$, the alkaline phosphatase $6.9 \mathrm{KA}$ units, SGOT 33 S.F. units, total plasms protein $6.5 \mathrm{G}$ per $100 \mathrm{ml}$, with a serum albumin of $3.6 \mathrm{G}$ per $100 \mathrm{ml}$ and serum globulin $2.9 \mathrm{G}$ per $100 \mathrm{ml}$. Agglutination tests for brucellosis and typhoid were negative. Blood culture was negative and repeated stool examination showed no abnormality.

He was transferred by air to the United Kingdom and admitted to the Queen Alexandra Military Hospital on 27th October 1965.

On examination there was slightly increased pigmentation of the skin over the dorsum of the distal phalanges of the fingers and toes. The liver was slightly enlarged but was not tender (Fig. 4). The spleen was enlarged and firm on palpation. The supratrochlear glands were palpable as were some small axillary and cervical glands. The patient looked well and had a good appetite. Since the onset of his illness he had lost 3 stones in weight but had regained about one stone over the previous ten days. The temperature chart showed a swinging fever of up to $104^{\circ} \mathrm{F}$ until the 10 th October 1965 and then fell to become a low grade fever, for some days, and then returned to its original character.

The haemoglobin was $13.2 \mathrm{G}$ per $100 \mathrm{ml}$, with a packed cell volume of 38 per cent, a mean corpuscular haemoglobin of 34 per cent, and mean cell volume of $104 \mathrm{~m} \mu$. The white cell count was 3,700 per $\mathrm{cmm}$ with a normal differential and the platelet count was 160,000 per cmm. The ESR was $15 \mathrm{~mm}$. in the first hour. Blood films failed to show Leishman-Donovan bodies. The serum bilirubin was less than $1 \mathrm{mgm}$ per cent, the alkaline phosphatase $12.3 \mathrm{KA}$ units. SGOT 27 units and SGPT 16 units. The prothrombin time was 14 seconds against a control of 13 seconds. The formol-gel test was negative. The total plasma protein was $6.8 \mathrm{G}$ per cent of which $3.7 \mathrm{G}$ was albumin and $3.1 \mathrm{G}$ was globulin with a beta globulin of $.54 \mathrm{G}$ and gamma globulin of $1.94 \mathrm{G}$. The 
serum folate was $3.2 \mathrm{~m} \mu \mathrm{g}$ per $\mathrm{ml}$ and $3.7 \mathrm{~m} \mu \mathrm{g}$ per $\mathrm{ml}$ and the serum B $12435 \mu \mu \mathrm{g}$ per $\mathrm{ml}$ and $630 \mu \mu \mathrm{g}$ per $\mathrm{ml}$. Bone marrow biopsy was again performed and showed scanty Leishman-Donovan bodies.

Treatment was instituted with Pentostam $0.6 \mathrm{G}$ intravenously lasting for 10 days with rapid improvement in the patient's condition.

\section{Discussion}

The diagnosis of fully developed kala-azar, though a rare disease is not difficult if the condition is kept in mind. The combination of high fever, a good general condition, progressive firm enlargement of the spleen and general depression of all elements of the blood is characteristic. All four patients eventually showed this characteristic picture, with a remittent fever often with twice daily rises in temperature, good general condition, a firm large spleen and with a white cell count of less than 2,000 per $\mathrm{cmm}$. The platelet count in the two more severe cases fell to less than 100,000 per $\mathrm{cmm}$ and one patient developed a severe purpuric rash. Bleeding secondary to thrombocytopenia is a feature of some cases. Epistaxis is the commonest manifestation but bleeding from the bowel, haematuria or bleeding from other sites also occur. Anaemia of severe degree was present only in the most gravely ill patient and he required blood transfusion on two occasions.

The finding of a significantly raised gamma globulin lends further support to the diagnosis which is finally confirmed by demonstration of the parasites. They should be sought in blood, lymph nodes if enlarged, bone marrow and spleen in that order. Diligent search will reveal the parasites in nearly every case.

In the earliest stages of kala-azar the clinical picture may be less characteristic. The fever may be undulant, of low grade, or there may be no fever at all. At first the spleen is not palpable as was shown in case number 2 , becoming palpable on the sixth day of illness. Once palpable the spleen progressively increases in size at the rate of one inch every month. It has been likened in this respect to the pregnant uterus. Kala-azar is the cause of some of the largest spleens in medicine and the organ may come to fill the right iliac fossa.

Kala-azar means "black fever" and changes in pigmentation may be helpful in diagnosis. The first case showed a marked dusky pigmentation of the hands and face and patchy areas of pigmentation of the calves while the second and fourth patients who had a much less severe illness showed only minimal increase of pigmentation over the dorsum of the distal phalanges of the hands and feet. The coloured third patient had sought medical advice ten months prior to the onset of clinical kala-azar for patches of depigmentation over the upper part of the trunk, (Figs. 2 and 3).

Other points of interest in these cases are the raised serum transaminase levels in two of the patients with an alkaline phosphatase level of 49 K.A. units in one of them. These results presumably reflect hepatic damage by the parasite. The most severely ill patient showed a megaloblastic bone marrow with a serum folate level of $2.1 \mathrm{~m} \mu \mathrm{g}$. per $\mathrm{ml}$. and a positive FIGLU test.

Adequate treatment with Pentostam is said to be extremely effective in India. Kirk(9) preferred it to other drugs in the Sudan where the disease is known to be resistant to treatment and it has been used extensively in East Africa. Napier(10) believed that there was a drug of choice for each geographical area. Using the dosage schema of Manson-Bahr(11), all patients appear to have made an excellent recovery. 


\section{Summary}

The clinical features of four cases of kala-azar from the Aden Protectorate are given in detail. Leishmania were found in the marrow of two patients and only after splenic biopsy in the other two. Parasites were not seen in the blood of any of the patients.

Pentostam was used in treatment with excellent results.

\section{REFERENCES}

(1) Felsani, F. (1959). Osservazioni Nosografiche nel bassopioano de Yemen Arch. Ital. Sci. Med. Trop. e. Parrasit. V. 40 (5), 219-268.

(2) Manson-Bahr, Philip. (1960). Mansons Tropical Diseases. Cassell, London. 15th Ed. Page 133.

(3) De Alencar, J. E. (1962): Investigations in a focus of kala-azar in Daraiba Brasileira, Rio de Janeiro. Oct.-Dec, No. 4. 367-370.

(4) HeISCH, R. B. (1963). Is an animal reservoir of kala-azar in Kenya. East African Med. J. July No. 7. 359-362.

(5) Van Peenan,'P. F. D., ReId, I. P., Jr. (1963). Leishmaniasis in the Sudan Republic. 15. An outbreak of kala-azar in the Khar Fahn Area, Upper Nile Province. J. Trop. Med. and Hyg. Oct. 10. 252-254.

(6) Hourn, R. (1963). Epidemiological data on Leishmaniasis in France and deductions for its prevention. Ann. Parasit. Humaine et Comparee. 3, 379-438.

(7) WRIGHT, M. I. (1959). Kala-azar of unusual duration, associated with agammaglobulinaemia. Brit. Med. J. May 9. 1218-21.

(8) Scovel, F. G. (1944). Kala-azar. A review of its incidence and epidemiology in China and clinical observations on 585 cases. Ann. Int. Med. 21, 607.

(9) KIRK, R. (1945), Quoted Wemyon C.M. Trans. R. Soc. Trop. Med. Hyg. S. 9, 37.

(10) NAPIER, L. E. (1949). J. Trop. Med. Hyg. 52, 243.

(11) Manson-Bahr, P. E. C. (1959). Trans. R. Soc. Trop. Med. Hyg. 53, 132.

\section{Erratum}

The report in our issue No. 4 of October, 1965 concerning the election of Sir. John Boyd, O.B.E., M.D., F.R.C.P., F.R.S.; as an Honorary Fellow of the Royal Society of Health is incorrect.

The election is to Honorary Fellowship of the Royal Society of Medicine and we wish to tender our apologies for the error in reporting.

The following appointments have been announced:-

\section{Honorary Consultants to the Ministry of Defence (Army)}

Physician

Gastro-enterology

Haematology

Radiotherapeutics

Physiology and Nutrition

Endocrinology
Sir Ronald Bodley Scott, K.C.V.O., M.A., D.M., F.R.C.P., in succession to the late Dr. E. R. Cullinan.

Dr. R. R. Bomford, D.M., F.R.C.P., in succession to the late Dr. E. R. Cullinan.

Professor J. V. Dacie, M.D., F.R.C.P., in succession to Sir Ronald Bodley Scott.

Mr. T. M. Prossor, B.Sc., F.R.C.S.(Edin.), F.F.R., in succession to Sir Stanford Cade. His appointment as Honorary Consultant to the Queen Alexandra Military Hospital has automatically ceased.

Dr. R. Passmore, M.A., B.M., B.Ch., in succession to Sir David Cuthbertson.

Dr. J. D. N. Nabarro, M.D., F.R.C.P., in succession to Dr. A: W. Spence.

Honorary Consultants to The Queen Alexandra Military Hospital, Millbank

Neoplastic Surgery

Mr: E. Stanley Lee, M.S., M.B., F.R.C.S.

Radiotherapeutics

Dr. K. A. Newton, M.B., B.Sc., D.M.R., M.R.C.P. 